養殖魚に拈けゼノバイオティックスの比較薬理学的研究

(平成 15 年度日本水産学会賞進歩賞受賞)

\author{
上野隆 二* \\ (三重大学生物資源学部)
}

Comparative pharmacological studies of xenobiotics in farmed fishes

\title{
RYUJI UENO*
}

Faculty of Bioresources, Mie University, Tsu, Mie 514-8507, Japan

高等動物の体内に入り込む物質のうち，その動物の体 構成分でも栄養成分でもない物質は生体にとっては異物 になる。異物のうち，低分子の有機化合物で，脂溶性が あり，薬理・毒性作用のある物質はゼノバイオティック ス（生体異物）と呼ばれている。水産分野におけるゼ） バイオティックスには, 水系媒介による工場污染, 農薬 などや養殖場に打ける水産用医薬品がある。近年, 我が 国の水産養殖技術の発展により魚介類の集約的な高密度 飼育が可能になり, 水産養殖業の著しい発展がなされて いる。これに伴い発生する種々の疾病を予防または治療 するために数多くの水産用医薬品が用いられている。水 産用医薬品の投与は, 魚介類の食品衛生面に抢ける魚体 内残留の久ならず過剩または過少投与による環境污染, 耐性菌の増加など種々の問題が生じてくる。したがっ て, 水産用医薬品の有効性, 安全性を考慮した適切な投 薬法が必要となる。本研究は, 養殖魚に用いられる種々 のゼノバイオティックスのうち, 水産用医薬品（主とし て抗菌性物質）について比較薬理学的視点から行った。

\section{HPLC による定量法の開発・改良}

生体内の薬物動態を知るには, 投与後の薬物濃度を知 る必要がある。その定量法には, 生物検定, 蛍光測定法 および高速液体クロマトグラフィー（HPLC）などがあ るが，生物検定および蛍光測定法は感度や代謝物に対し て非特異的である。一方, HPLC 法は高い感度と分離 能を有することから近年よく用いられている。HPLC を用いた定量法は，いずれも定量妨害の少ない血液や筋 肉に関するものが多く, 特に養殖魚類は筋肉中に多量の 脂質を含むため, 前処理に手間を要する。また, 肝蔵, 腎臓, 脾蔵, 胆汁などといった排泄器官も分析する必要
があるが，種々の妨害物質が存在する。そこで，本研究 を遂行するにあたり，HPLCの定量法の開発から着手 した。その結果，オキシテトラサイクリン (OTC), 1) オキソリン酸 $(\mathrm{OA}),{ }^{2)}$ ナリジクス酸 $(\mathrm{NA}),{ }^{3)}$ スルファ モノメトキシン $(\mathrm{SMM}), 4,5)$ スルファジメトキシン $(\mathrm{SDM}), 4,5)$ ニフルスチレン酸 $\left.(\mathrm{NFS}),{ }^{6}\right)$ ミロキサシン $\left.(\mathrm{MLX}),{ }^{7}\right)$ フロルフェニコール $(\mathrm{FF})^{8)}$ などの定量法を 開発・改良し，いずれも農林水産省による残留分析法の 確立基準（添加回収率 70-80\% 以上，変動係数 10\% 以 下，検出限界 0.05-0.1 ppm）に充分適合できた。また， 採血後約 30 分以内で定量する簡易 HPLC 法も開発した。 $\mathrm{OTC}^{9}$ 抢よび $\mathrm{FF}$ (未発表) は単独で，OA, SMM とそ のアセチル体，SDM とそのアセチル体，MLX は同時 定量可能であった。 100 本方法は筋肉にも対応できるた め, 養殖魚の残留検査のためのモニタリングとしても利 用できる。

\section{2. モデル解析による魚種間の比較薬物動態と薬物投与 量の推定}

通常, 薬物動態解析では強制経口投与後の血中薬物濃 度データおよび血管内投与後の血中薬物濃度データを用 いる。前者の場合, 種々の影響（餌料形態, 薬物の溶解 率, 生体利用率など）なく, 循環系に入るため, 魚種間 の動態解析に適している。しかし, パラメーターの比較 は, 同一モデルでなくてならない。一方, 強制経口投与 後のデータは吸収・消失速度や薬物の分布状態 (分布容) の評価が出来るため, 薬物投与量の評価などに利用され る。さらに，強制経口投与抢よび血管内投与後の血中薬 物濃度データをモーメント解析することにより, 生体利 用率を算出することが出来る。ここでは，養殖魚類でよ

* Tel : 81-59-231-9568. Fax : 81-59-231-9568. Email : ueno@bio.mie-u.ac.jp 
く使用される OTC, OA, SMM に抢ける血管内投与後 の血漿内濃度を科の異なる魚種間（ウナギ，ニジマス， ブリ）で薬物動態を比較した。これらはいずれも肉食魚 であるが，生息水温域が異なる。それぞれウナギはウナ ギ科で, 広域水温, 二ジマスはマス科で冷水域, ブリは アジ科で温水域である。本研究に打いて，血管内投与の 動態解析ではすべて2-コンパートメントで解析された。 OTCでは, ウナギ, ${ }^{11)}$ ニジマス, ${ }^{12)}$ ブリ13)の順に, 分布 速度半減期 $\left(\mathrm{T}_{1 / 2 \alpha}\right)$ では, $2.08,1.53,0.735 \mathrm{~h}$ であり, 消失半減期 $\left(\mathrm{T}_{1 / 2 \beta}\right)$ は $115,60.3,22.5 \mathrm{~h}$ あった。一方, 魚体内からの薬物の除去率を表す総クリアランス $\left(\mathrm{Cl}_{\mathrm{B}}\right)$ は, $2.98,16.2,15.1 \mathrm{~mL} / \mathrm{kg} / \mathrm{h}$ であった。これらの結果 から, ウナギの場合, 投薬後ゆっくりと組織内に分布 し，排泄されるが，ブリの場合，全くその反対であっ た。すなわち，分布も排泄も非常に早く代謝された。ま

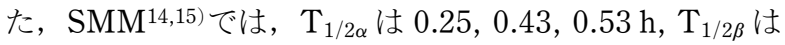
86.6, 34.7, $5.78 \mathrm{~h}, \mathrm{Cl}_{\mathrm{B}}$ は 3.38, 18.5, $66.7 \mathrm{~mL} / \mathrm{kg} / \mathrm{h}$ であ った。さらに $\mathrm{OA}^{12)}$ (ウナギおよびブリ (未発表)）を 用いた場合もほぼ OTC と同様の結果が得られた。この ことから薬物動態速度は, 薬物の種類よりも魚種によっ て非常に異なるといえる。なお, 本研究では, 上記薬物 以外に, NA, ${ }^{16)} \mathrm{NFS},{ }^{16)} \mathrm{MLX},{ }^{7)} \mathrm{FF}^{8}$ の体内動態も報告 した。

生体利用率（F）はバイオアベイラビリティとも呼ば れ，体循環血中に入った薬物量の投与された薬物量に対 する比率であり，投与された部位からの薬物の吸収の割 合を示す指標である。通常, 経口投与された薬物は消化 管より吸収され血液中に出現するが，投与された薬物の 全量が吸収され体循環血中に入るとは限らない。一方, 血管内投与された薬物は直接血中に入るため, 全量が体 循環血中に入ることになる。経口投与後の血中薬物濃度 一時間曲線下面積 (AUC) と血管内投与後の AUC の 比率は F と定義される。AUC から算出された OTC の 生体利用率（F）は，ウナギで $0.69 \%, 11)$ ニジマスで $0.6 \%,{ }^{12)}$ ブリで $0.6 \%,{ }^{13)}$ と非常に低い值を示した。 OTC は，飼料中の蛋白質との結合や $\mathrm{Mg}, \mathrm{Ca}$ などの金 属イオンとのキレート形成により不溶性となり，消化管 からの吸収が低下（脂質膜への通過が困難）すると考え られる。SMM の場合, F はウナギ，ニジマス，ブリの 順でそれぞれ $24,19,16 \%$ であり, OTC と同様, 魚種 間での差はあまり認められなかった。また，ウナギでは MLXのF は 87.9\%, 9) NA ではニジマスで 89.6\%, 16) $\mathrm{FF}$ では $74.6 \%$ (未発表) やアンピシリン (AMP) で はブリで $74.6 \%$ (未発表) であり，F は魚種よりもむ しろ餌料形態や薬物, 水温などのの違いにより異なると 考えられる。

経口投与後の血中濃度データ, $\mathrm{F}$ 值および自由摂䬣で の血中濃度データを基にして, 現行の投薬基準法を評価
し，理想投与量を算出した。本研究において，ウナギや ニジマスへの現行投薬法はむしろ環境負荷を与える過剩 投与の傾向，またはほぼ啇正投与であった。しかし，ブ リの場合，すべての薬物 (OTC, OA, FF, AMP, SMM) に打いて，薬剤耐性菌の発生を予知するような過少投与 であった。すなわち，現行の用法・用量で 1 日 1 回投 与した場合，次回の投与時までにはすでに目的とする病 原菌の MIC（最小発育阻止濃度）以下になっていた。 そこで，1例として，ブリの疾病で常用される $\mathrm{OA} の$ 理 想投与量を算出してみた。現行の使用基準では養殖ブリ は，経口投与（自由拱餌）で， $30 \mathrm{mg} / \mathrm{kg} /$ 日である。こ れを 1 日 1 回投与し，かつ自由拱慨した場合， $70 \%$ （未発表）の取り込みになる。これを上記の強制経口投 与後の血中濃度データをモデル解析し, シミュレーショ ンを描くと 24 時間後にはすでに，MIC（代表的な類結 節症の病原菌 Pasteurella piscicida では $0.2 \mu \mathrm{g} / \mathrm{mL}$ ) 以 下になる。また，実際に投薬実験した場合でも同様の結 果を得た。そこで, 薬の取り込みの安全性を考慮し, 目 的の MIC の 5 倍の範囲で血中濃度を維持する濃度を算 出すると，初回投与を $17-20 \mathrm{mg} / \mathrm{kg}$, 維持投与を 9-15 $\mathrm{mg} / \mathrm{kg}$ で， 4-6 時間毎投与すれば，薬剤耐性菌の発生 の憂いなく，治療できると思われる。なお，ブリでの OA 耐性菌の発生は非常に高く, 1986 年から 1988 年に 分離されたブリ由来のP. piscicida の $\mathrm{OA} に$ 対する薬剂 感受性 MIC 值は供試株の約 $1 / 3$ が $1.56 \mu \mathrm{g} / \mathrm{mL}$ であっ たと報告されている。18,19) したがって, ブリの場合，現 行の使用基準の見直しが急務であるといえる。

\section{3. 魚類における薬物代謝および代謝経路}

魚類の薬物代謝については, 哺乳類に比べて比較的単 純といわれている。OAの場合, 哺乳類では, OA は腎 臓に移行し, 尿中に排泄される。オキソリン酸の代謝物 は，ラット，ウサギ，イス20)では未変化体抢よび未変 化体のメチレンジオキシ環が開環し，側鎖の水酸基がメ チル化された 7-OHOA ならびにそのグルクロン酸抱合 体の存在が報告されている。ラット 21 の尿中ではその 他に 7-OHOA の異性体である 6-OHOA とそのグルク ロン酸抱合体も検出された。

魚類に抢ける OA の胆汁中代謝物は, 淡水産魚（二 ジマス, ウナギ, ティラピア） と海水産魚（マダイ, マ アジ，ブリ，ヒラメ）との間に代謝物の差異があっ た。 ${ }^{21)}$ 前者の場合, 未変化体, 7-OHOA 抢よび6OHOA のグルクロン酸抱合体が, 後者の場合, 7OHOA および 6-OHOA のグルクロン酸抱合体が検出さ れたが，未変化体の抱合体はいずれも検出されなかっ た。しかしながら，ブリ経口投与後の胆汁の $\beta$-グルク ロニダーゼ処理により，未変化体のグルクロン酸抱合体 の存在も報告されている。 ${ }^{3)} \mathrm{OA}$ を経口投与した場合， 
ニジマス，アマゴ，ブリにおいても腎蔵に多く蓄積され ることから，魚類でも OAの尿中の排泄は主要な経路 といえる。年一般に, 淡水産魚に抢ける OA の体内残留 時間は海水産魚に比べて長い。その原因として環境水, すなわち，浸透圧調節作用の違いと報告されている。22)

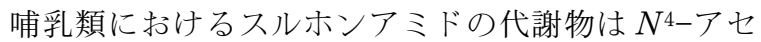
チル体とグルクロン酸抱合体の 2 つ型が報告されて いる。一方, 魚類に打いて, コイ, 23) ニジマス ${ }^{24)}$ 中の $N^{4}$-アセチル体の体内動態についての報告がある。ニジ マスの尿や胆汁中から 5 種のスルホンアミドのアセチ ル化された代謝物とグルクロン酸抱合された代謝物の存 在も確認された。25) ニジマス, ウナギ, ブリでは, SMM がアセチル化掞よびグルクロン酸抱合されてい る。726) さらに，グルクロン酸抱合化よりもアセチル化 される代謝物が大部分であり, また, グルクロン酸抱合 された $N^{4}$ ーアセチル体の存在も報告された。SMM はア セチル化されることによって抗菌作用を失うが，代謝さ れたアセチル体は難溶性のため, 体内で尿結石を生成 し, 腎障害を起こす要因となる。また, 哺乳類では, ア セチル体の脱アセチル化も報告されている。それゆえ， 魚体そのものへ影響の久ならず, 抗菌作用のある未变化 体への変換の可能性は, 食品衛生上の問題となる。

\section{4. 閉鎖系養殖場における薬物分布と環境評価}

ニジマスやウナギなどの閉鎖系養殖場において，薬物 投与した場合, 残存薬物によって池水, 沈殿物が污染さ れ，それらの近辺への廃棄により多大な環境負荷への影 響が考えられる。養殖ニジマス抢よびサケの治療後にお ける野生の魚類抢よび沈殿物の中の OTC の残留物の存 在を報告し，また多くの OTC 耐性細菌が野生の魚の腸 から分離されたことを報告された。 法, 用量によって投薬された OTCの養鰻場における分 布状況を調べた。11) 規定どおり経口投与された OTC の 血中濃度は, 最終投薬日には最高水準 $(0.64 \mu \mathrm{g} / \mathrm{mL})$ に達した。しかしながら，この濃度はウナギの病原菌で あるAeromonus punctata やA. liquefaciens に対する OTCの MIC (0.7-1.25 $\mu \mathrm{g} / \mathrm{mL})$ を超えることなく, 明 らかに過少投与と判断された。投薬中に, 池水の中の OTCのレベル $(0.23-0.27 \mu \mathrm{g} / \mathrm{mL})$ はほぼ一定であっ たが，投薬終了後速やかに減少し，5 日目で検出限界以 下になった。一方, 沈殿物中には, OTC が大量に蓄積 したが，終了後，27 日目で検出されなかった。OTC投 薬後の養鰻場に抢ける分布状況を概算してみると, 沈殿 物に $74 \%$, 池水に $25.9 \%$, 魚体内利用は $0.07 \%$ であっ た。すなわち，投薬された OTC の $99.9 \%$ が環境に流 出し, 環境污染や耐性菌の出現が示唆された。この主な 理由として, 投薬する際の練り慨が原因と考えられる。 OTC の代替薬の使用か，もっと効率のよい投薬用餌料
の開発が必要とされる。

\section{5. 養殖ウナギにおける簡易残留検査法}

本研究は養鰻業界が行う自主検査システムの構築に必 要な医薬品の簡易残留検査を開発することを目的とし た。すなわち, 養殖ウナギの食品としての安全性を確保 するとともに，その客観的な安全性評価により付加価値 向上を目指すものである。まず，技術的に簡便で高度な 機器等を必要としないバイオアッセイ法, すなわち, ウ ナギ用医薬品全般に感受性を有する供試菌株を選定し， 検査部位や培養条件などの検查条件を調べ，ウナギにお ける直接バイオアッセイ法を開発した。28,29) 一方, バイ オアッセイ法を技術補完し, 安全性を確認できる高感度 で迅速な検査法が必要である。そこで, 指導機関が行う 高感度で迅速な検出法として HPLC 簡易法のシステム 化も考察した。30)これらの簡易法はすでに愛知県の養鰻 漁協の自主検査に使用されており, 養殖業者にとっては すでに出荷に伴う作業の 1 つとして認知されている。

\section{6. おわりに}

わが国で現在使用されている水産用医薬品の多くは, 治療効果すなわち，生残率を目的とした投薬量で設定し ているため, 実際に魚体内血中濃度を調べた場合, 薬物 の過剩投与や過少投与を示す結果も出ている。最近, 消 費者は, 食の安全性に対し, 非常に関心を持っているた め, 養殖魚の品質評価を厳しくしなければならない。し たがって, 今後食品としての養殖魚の品質向上や投薬に よる養殖場への環境負荷低減を考慮した, 可能な限り適 正な投薬法が必要といえる。

\section{文献}

1) Ueno R, Uno K, Kubota SS. Determination of oxytetracycline in fish tissues by high performance liquid chromatography. Nippon Suisan Gakkaishi 1989; 55: 12731276.

2) Ueno R, Horiguchi Y, Kubota SS. Levels of oxolinic acid in cultured yellowtail after oral administration. Nippon Suisan Gakkaishi 1988; 54: 479-484.

3) Uno K, Aoki T, Ueno R. Pharmacokinetics of nalidixic acid in cultured rainbow trout and amago salmon. Aquaculture 1992; 102: 297-307.

4) Ueno R, Uno K, Kato M, Kubota SS, Aoki T. Simultaneous determination of sulfamonomethoxine, sulfadimethoxine and their $\mathrm{N}^{4}$-acetylated forms in fish tissues by high performance liquid chromatography. Nippon Suisan Gakkaishi 1991; 57: 549-554.

5) Uno K, Aoki T, Ueno R. Pharmacokinetics of sulphamonomethoxine and sulphadimethoxine following oral administration to cultured rainbow trout (Oncorhynchus mykiss). Aquaculture 1993; 115: 209-219.

6) Uno K, Aoki T, Ueno R. Pharmacokinetics of sodium nifurstyrenate in cultured yellowtail after oral administration. Aquaculture 1993; 116: 331-339. 
7) Ueno R, Okada Y, Tatsuno T. Pharmacokinetics and metabolism of miloxacin in cultured eel. Aquaculture 2001; 193: 11-24.

8）上野隆二, 寺門弘悦, 青木恭彦. 高速液体クロマトグラ フィーによる養殖ブリ中のフロルフェニコールの定量. 三重大学生物資源紀要 2000; 24: 23-29.

9) Ueno R, Uno K, Aoki T. Determination of oxytetracycline in blood serum by high performance liquid chromatography with direct injection. J. Chromatogr. 1992; 574: 333-335.

10) Ueno R, Aoki T. High-performance liquid chromatographic method for the rapid and simultaneous determination of sulfamonomethoxine, miloxacin and oxolinic acid in serum and muscle of cultured fish. J. Chromatogr. 1996; B682: 179-181.

11) Ueno R, Kinoshita A, Wakabayashi J. Comparative pharmacokinetics of oxytetracycline in eel and its fate in a closed aquatic environment. Aquaculture 2004 (in press).

12) Björklund HV, Bylund G. Pharmacokinetics and bioavailability of oxolinic acid and oxytetracycline in rainbow trout (Oncorhynchus mykiss). Acta Vet. Scand. Supple. 1991; 87: 298-299.

13) Ueno R, Uno K, Aoki T. Pharmacokinetics and bioavailability of oxytetracycline in cultured yellowtail Seriola quinqueradiata. Proceedings of Diseases in Asian Aquaculture 1995; 2: 523-531.

14) Ueno R. Pharmacokinetics and bioavailability of sulfamonomethoxine in cultured eel. Fish Path. 1998; 33: 297 -301 .

15) Uno K, Aoki T, Ueno R, Maeda I. Pharmacokinetics and metabolism of sulphamonomethoxine in rainbow trout (Oncorhynchus mykiss) and yellowtail (Seriola quinqueradiata) following bolus intravascular administration. $A$ quaculture 1997; 153: 1-8.

16) Uno K, Aoki T, Ueno R, Maeda I. Pharmacokinetics of nalidixic acid and sodium nifurstyenate in cultured fish following bolus intravascular administration. Fish Path. 1996; 31: 191-196.

17) Björklund HV, Bylund G. Comparative pharmacokinetics and bioavailability of oxytetracycline in rainbow trout (Oncorhynchus mykiss). Xenobiotica 1991; 21: 1511-1520.
18）和田有二. $1983 ； 1982$ 年に愛媛県内で分離された $\alpha^{-}$ haemolytic Streptococuss sp. およ び Pasteurella piscicida の薬剤感受性. 愛媛県水産試験場研究報告 1983; 3: 1421.

19）楠田理一，杉浦浩義, 川合研児. 1986 年から 1988 年に 養殖ブリから分離されたPAsteurella piscicidaの薬剤感受 性. 日水誌 1990; 56: 239-242.

20) Crew CM, Melgar MD, Haynes LJ, Gala RL, DiCarlo FJ. Comparative metabolism of oxolinic acid by the rat, rabbit and dog. Xenobiotica 1971; 1: 193-201.

21）藤原充雄, 大塚峰三, 佐藤喜重. ${ }^{14} \mathrm{C}$-標識 oxolinic acid の生体内運命に関する研究（第 3 報）ラットにおける尿 中代謝物について. Radioisotopes 1975; 24: 22-28.

22）石田典子. 淡水魚および海水魚におけるオキソリン酸の 組織内濃度の比較. 日水誌 $1990 ; 56:$ 281-286.

23) Grondel JL, Nouws JFM, Haenen OLM. Fish and antibiotics: Pharmacokinetics of sulphadimidine in carp (Cyprinus carpio). Vet. Immunol. Immunopathol. 1986; 12: 281286.

24) Ginneken VJ, Nouws JFM, Grondel JF, Diessens F, Degen JM. Pharmacokinetics of sulphadimidine in carp (Cyprinus carpio L.) and rainbow trout (Salmo gairdneri Richardson) acclimated at two different temperature levels. Vet. Q. 1991; 13: 88-96.

25) Ishida N. Metabolites of five sulfa drugs in the bile and urine of rainbow trout. Nippon Suisan Gakkaishi 1989; 55: 2163-2166.

26) Ueno R, Uno K, Aioki T. Pharmacokinetics of sulphamonomethoxine in cultured yellowtail after oral administration. Food Research International 1994; 27: 33-37.

27) Bjorklund HV, Rabergh CMI, Bylund G. Residues of oxolinic acid and tetracycline in fish sediments form fish farms. Aquaculture 1991; 97: 85-96.

28）宮川宗記. 養殖ウナギにおける抗菌性物質の簡易残留検 查法. 水産養殖 $2000 ; 48: 117-122$.

29）宮川宗記. 養殖ウナギにおける抗菌性物質の簡易検査に 用いる直接バイオアッセイ法の改良. 水産養殖 2000; 48: 221-225.

30）宮川宗記, 竹内嘉夫, 川原佐妃子, 上野隆二. 養殖ウナ ギに打ける抗菌性物質の HPLC 簡易残留検査法. 水産養 殖 2000; 48: 553-557. 